\title{
EVALUATION OF RESISTANCE OF CUCUMBER CULTIVARS TO THE VEGETABLE LEAFMINER (Liriomyza sativae Blanchard) (DIPTERA: AGROMYZIDAE) IN GREENHOUSE
}

\author{
Moslem Basij $^{*}$, Alireza Askarianzaeh${ }^{1}$, Shahriyar Asgari², Saeid Moharramipou $^{3}$, and Ramin Rafezi²
}

The leafminer, Liriomyza sativae Blanchard, is distributed around the world and is an important pest of vegetables and ornamentals. Given the resistance potential of the leafminer to current insecticides, the use of resistant plant cultivars and parasitoids could be effective integrated pest management (IPM) strategies against it. Cucumber (Cucumis sativus L.) is a preferred host for this insect. Seventeen cultivars of cucumber have been evaluated to study resistance mechanisms to L. sativae. All cucumber cultivars were evaluated in screening tests in greenhouse with indices such as the number of leafminer stings, the number of larval mines, the proportion of larval mines to leafminer stings, and the rate of injury. Significant differences $(\mathrm{p}<0.01)$ were found among cultivars, as well as significant correlations among all evaluated indices. Cucumber cultivars were ranked by the cluster method based on all measured characters and were classified into four groups: susceptible, semi-susceptible, semi-resistant, and resistant. Trials of antibiosis resistance of cucumber cultivars were conducted in a growth chamber and were evaluated with biological indices of insect activity including oviposition period, larval and pupal duration, percentage of larval and pupal mortality, and the sex ratio among selected cultivars. Significant differences were found for all indices except pupal weight and the sex ratio. The cultivars were analyzed by the cluster method based on all measured characters and were divided into three groups including sensitive, slightly resistant, and semi-resistant. No cultivar was immune to injury.

Key words: Cucumber cultivar, screening, antibiosis, Cucumis sativus.

$\mathrm{C}$ ucumber (Cucumis sativus L.), which is the main greenhouse vegetable in Iran, is attacked by different pests, including leafminers (Fathipour et al., 2006). Agromyzid leafminers are found worldwide and have an economically important impact on many agricultural crops (Kaspi and Parrella, 2005; Hondo et al., 2006). The leafminer Liriomyza sativae Blanchard is a major pest of greenhouse cucumbers in Iran and a wide variety of vegetables and ornamental crops throughout the world (Parrella, 1983; Reitz and Trumble, 2002). Damage is caused mostly by larvae that feed and mine the mesophyll and by the female feeding behavior, puncturing the leaf with its ovipositor and feeding on the leaf sap, which decreases photosynthesis (Parrella, 1983). As well, they may transmit plant pathogens during oviposition (Johnson et al., 1980; Minkenberg and Helderman, 1990). Chemical control of leafminers usually lasts only a short period of time and adult control with contact insecticides is often

${ }^{1}$ Shahed University, Faculty of Agricultural Sciences, P.O. Box: 18151/159 Tehran, Iran.

*Corresponding author (moslembasij@yahoo.com).

${ }^{2}$ Agricultural and Natural Resources Research Center of Tehran Province, Postal Code: 3371635951 Tehran, Iran.

${ }^{3}$ Tarbiat Modares University, Faculty of Agriculture, P.O. Box: 14115-111, Tehran, Iran.

Received: 12 January 2011

Accepted: 28 May 2011. ineffective because flies can easily move around, and the treated field is subject to reinfestation from adjacent untreated crops and weeds (LeStrange et al., 1999).

Leafminers have developed a high degree of resistance to a broad range of insecticides (Mason et al., 1987; Parrella and Trumble, 1989; Keil and Parrella, 1990). Therefore, it is essential to develop alternative strategies for leafminer management. Resistant varieties remain the most economical means of insect control. Their development could reduce pesticide use, which would be beneficial to growers, consumers, and the environment. Screening for antixenotic (nonpreferential) plants that have traits that make them unattractive to insect pests to feed or to lay their eggs is usually carried out in choice tests where insect can choose among different plant genotypes for feeding or oviposition (Mou and Liu, 2004). Mou and Liu (2004) screened more than 200 lettuce (Lactuca sativa L.) accessions and identified sources of resistance. Mou (2008) screened 345 accessions of spinach (Spinacia oleracea L.) for evaluation of antixenosis resistance and found that resistant genotypes have fewer pores than commercial cultivars. Antibiosis and antixenosis resistance to Liriomyza trifolii (Burgess) in tomato (Lycopersicon esculentum Mill.) hybrids were reported by Erb et al. (1993). Studies of antixenosis resistance divided 19 bean (Phaseolus vulgaris L.) cultivars into three main groups, including semi-resistant, 
moderately resistant and semi-susceptible (Zahiri et al., 2003). Oviposition deterrence of chrysanthemums to $L$. trifolii has been investigated by Dijk et al. (1993), and of three melon (Cucumis melo L.) genotypes antixenosis to the leafminer was the main factor (Bordat et al., 1996) on several greenhouses cultivars.

\section{MATERIALS AND METHODS}

\section{Rearing methods}

To rear vegetable leafminer, individuals were collected from cucumber greenhouses in suburbs of Tehran, Iran, in August 2008. Liriomyza sativae larvae were reared on cucumber, $C$. sativus cv. Adrian and maintained at $25 \pm 1$ ${ }^{\circ} \mathrm{C}, 65 \pm 5 \% \mathrm{RH}$, and a 16:8 $\mathrm{h}$ photoperiod. The flies used in this study had been reared on cucumber for 5 months. To reduce any inbreeding effects, wild flies were added regularly.

Seventeen cultivars of cucumber were screened for leafminer resistance, including 'Vikima', 'Korazh', 'Karim', 'Soltan', 'Green magic', 'Royal', 'Evergreen', 'Jiroft 1', 'Khasib', 'Zohal' (greenhouse), 'Service plus', 'Maximus F1', 'Victor', 'Super dominus' (field), and local cultivars 'Sanandaj', 'Gorgan', and 'Roodbar'. Seeds were sown in $10 \times 10 \times 10 \mathrm{~cm}$ plastic pots with a 2:1 sand:soil mix (by volume). Pots were placed in a growth chamber with supplemental fluorescent lighting.

\section{Screening experiments}

Experiments were conducted at the Agricultural Research Station, Varamin, Iran, in 2009. Four weeks after planting, all cultivars were arranged in a randomized complete block design (RCBD) with five replicates, with each plot consisting of one plant in a pot. Spacing was $30 \mathrm{~cm}$ between plants and $100 \mathrm{~cm}$ between blocks in a greenhouse set at $25 \pm 2{ }^{\circ} \mathrm{C}, 55 \pm 5 \% \mathrm{RH}$ and a natural photoperiod. The number of leafminer stings, the number of larval mines, the proportion of larval mines to leafminer stings, and the rate of injury were determined. The number of stings was counted in $4 \mathrm{~cm}^{2}$ leaf areas with the highest sting density on a randomly selected leaf from each plant with the aid of a magnifying glass. The numbers of leafminer stings and larval mines and the rate of injury were evaluated on days 1,4 and 15, respectively.

The numbers of $1^{\text {st }}$ instar larvae were used as an indirect estimate of eggs laid in leaves because of the difficulty of detecting the eggs. The rates of larval injury were: without mines $=0$, mines $<10 \%$ of total leaf area $=1$, mines $10 \%$ $20 \%$ of total leaf area $=2$, and so on; mines $90-100 \%$ of total leaf area $=10$ (Singh and Weigand, 1996).

\section{Antibiosis trials}

Four weeks after planting, six cucumber cultivars were selected based on screening results in this research, plants were placed in $30 \mathrm{~cm}$ high $\times 30 \mathrm{~cm}$ wide $\times 40 \mathrm{~cm}$ deep insect cages covered with polypropylene fabric, and were arranged in a completely randomized design with 10 replicates. The experimental unit was a pot. All of them were kept in a growth chamber at $25 \pm 1{ }^{\circ} \mathrm{C}, 55 \pm 5 \% \mathrm{RH}$, and 16:8 h photoperiod. Four of same age fly pairs were released in each of the insect cages to feed on the plants. Flies were removed after day one and the plants were evaluated using biological indices of insects, including oviposition period, larval and pupal periods, percentage of larval and pupal mortality and sex ratio among selected cultivars.

\section{Leaf hairs in selected cultivars}

For the assessment of this trait, a fully expanded healthy leaf from each cultivar was cut and examined with binocular microscope at 50X magnification. A four-stage scale was used to score hair density of short, long, and glandular hairs.

\section{Statistical analysis}

Data were analyzed with the SPSS statistical program (SPSS, 2004) and were verified for normal distribution, except for rate of injury data, which were normalized by $\log _{10}$.

\section{RESULTS}

\section{Screening experiments}

Differences among cultivars were found significant for measured traits (Table 1). The number of leafminer stings was significantly different among cultivars. The mean $( \pm \mathrm{SE})$ number of leafminer stings per $4-\mathrm{cm}^{2}$ leaf area ranged from $2.80 \pm 0.37$ (Gorgan, a local cultivar) to $29 \pm 0.71$ ('Karim'). The number of larval mines was significantly different among cultivars. Larval mines varied from $0.8 \pm 0.49$ ('Gorgan') to $7 \pm 0.71$ ('Karim'). The proportion of larval mines to leafminer stings ranged from $0.19 \pm 0.01$ ('Korazh') to $0.55 \pm 0.08$ ('Green magic') (Table 2).

The correlation between leafminer stings and larval mines was positive and significant $(\mathrm{r}=0.85, \mathrm{p}<0.01)$. The mean rate of injury ranged from $1.40 \pm 0.40$ ('Gorgan', the cultivar with the most stings and the least damage) to $9.60 \pm 0.24$ ('Zohal', the cultivar with the greatest damage) (Table 2). No cultivar was immune to injury.

Means were compared separately for each index (Table 2). Leafminer activity among cultivars was significantly

Table 1.ANOVA of stings per 4- $\mathrm{cm}^{2}$ leaf area, larval mines, and proportion of mines to leafminer stings.

\begin{tabular}{|c|c|c|c|c|c|}
\hline \multirow[b]{2}{*}{$\begin{array}{l}\text { Source of } \\
\text { variation }\end{array}$} & \multirow[b]{2}{*}{$\begin{array}{l}\text { Degree } \\
\text { of } \\
\text { freedom }\end{array}$} & \multicolumn{4}{|c|}{ Mean squares } \\
\hline & & $\begin{array}{l}\text { Leafminer } \\
\text { stings }\end{array}$ & $\begin{array}{l}\text { Larval } \\
\text { mine }\end{array}$ & $\begin{array}{l}\text { Proportion of } \\
\text { larval mines } \\
\text { to leafminer } \\
\text { stings }\end{array}$ & $\begin{array}{c}\text { Rate of } \\
\text { injury }\end{array}$ \\
\hline Block & 4 & $6.558^{*}$ & $1.194 \mathrm{~ns}$ & $0.009 \mathrm{~ns}$ & 1.045 \\
\hline Cultivars & 16 & $319.347^{* *}$ & $17.423^{* *}$ & $0.057^{*}$ & $17.125^{* * *}$ \\
\hline Error & 64 & 2.352 & 0.987 & 0.032 & 0.445 \\
\hline $\mathrm{CV}$ & - & 12.97 & 26.65 & 29.37 & 20.03 \\
\hline
\end{tabular}

Significant $\mathrm{F}$ tests at $\mathrm{P}=0.05$ and 0.01 , respectively; ns: non significant. 
Table 2. Means ( \pm SE) of traits under study in leaves of 17 cucumber cultivars.

\begin{tabular}{lcclc}
\hline & $\begin{array}{c}\text { Number of } \\
\text { leafminer } \\
\text { stings }\end{array}$ & $\begin{array}{c}\text { Number } \\
\text { of larval } \\
\text { mines }\end{array}$ & $\begin{array}{c}\text { Proportion of } \\
\text { larval mines } \\
\text { to leafminer } \\
\text { stings }\end{array}$ & $\begin{array}{c}\text { Rate of } \\
\text { injury }\end{array}$ \\
\hline Eultivar & $17.80 \pm 1.24 \mathrm{~b}$ & $5.40 \pm 0.51 \mathrm{~b}$ & $0.30 \pm 0.03 \mathrm{abcd}$ & $5.40 \pm 0.50 \mathrm{c}$ \\
Kvergreen & $29.00 \pm 0.71 \mathrm{a}$ & $7.00 \pm 0.71 \mathrm{a}$ & $0.24 \pm 0.02 \mathrm{~cd}$ & $7.20 \pm 0.58 \mathrm{~b}$ \\
Karim & $28.00 \pm 0.001 \mathrm{a}$ & $5.20 \pm 0.37 \mathrm{~b}$ & $0.19 \pm 0.01 \mathrm{~d}$ & $7.00 \pm 0.70 \mathrm{~b}$ \\
Vorazh & $14.60 \pm 0.51 \mathrm{c}$ & $5.40 \pm 0.51 \mathrm{~b}$ & $0.37 \pm 0.04 \mathrm{abcd}$ & $5.20 \pm 0.37 \mathrm{c}$ \\
Zikima & $18.20 \pm 0.86 \mathrm{~b}$ & $6.80 \pm 0.58 \mathrm{a}$ & $0.38 \pm 0.04 \mathrm{bcd}$ & $9.60 \pm 0.24 \mathrm{a}$ \\
Khasib & $12.60 \pm 0.08 \mathrm{c}$ & $4.40 \pm 0.24 \mathrm{bc}$ & $0.36 \pm 0.03 \mathrm{abcd}$ & $5.40 \pm 0.50 \mathrm{c}$ \\
Jiroft1 & $14.20 \pm 0.86 \mathrm{c}$ & $4.40 \pm 0.40 \mathrm{bc}$ & $0.32 \pm 0.03 \mathrm{abcd}$ & $5.20 \pm 0.37 \mathrm{c}$ \\
Royal & $9.80 \pm 0.37 \mathrm{~d}$ & $4.20 \pm 0.37 \mathrm{bc}$ & $0.43 \pm 0.04 \mathrm{abcd}$ & $4.20 \pm 0.58 \mathrm{c}$ \\
Green magic & $5.20 \pm 0.37 \mathrm{e}$ & $2.80 \pm 0.37 \mathrm{~d}$ & $0.55 \pm 0.08 \mathrm{a}$ & $4.20 \pm 0.58 \mathrm{c}$ \\
Super dominus & $5.20 \pm 0.37 \mathrm{e}$ & $2.20 \pm 0.37 \mathrm{def}$ & $0.43 \pm 0.07 \mathrm{abcd}$ & $5.40 \pm 0.50 \mathrm{c}$ \\
Victor & $5.00 \pm 0.45 \mathrm{e}$ & $1.80 \pm 0.37 \mathrm{def}$ & $0.36 \pm 0.06 \mathrm{abcd}$ & $4.20 \pm 0.58 \mathrm{c}$ \\
Maximums & $5.20 \pm 0.37 \mathrm{e}$ & $2.20 \pm 0.37 \mathrm{def}$ & $0.45 \pm 0.10 \mathrm{abcd}$ & $4.40 \pm 0.50 \mathrm{c}$ \\
Service plus & $8.40 \pm 0.93 \mathrm{~d}$ & $4.20 \pm 0.58 \mathrm{bc}$ & $0.51 \pm 0.06 \mathrm{ab}$ & $5.40 \pm 0.50 \mathrm{c}$ \\
Soltan & $14.80 \pm 0.73 \mathrm{c}$ & $3.00 \pm 0.45 \mathrm{~cd}$ & $0.20 \pm 0.03 \mathrm{~d}$ & $4.20 \pm 0.37 \mathrm{c}$ \\
Roodbar Local & $5.40 \pm 0.68 \mathrm{e}$ & $2.40 \pm 0.24 \mathrm{de}$ & $0.50 \pm 0.12 \mathrm{abc}$ & $4.40 \pm 0.24 \mathrm{c}$ \\
Sanandaj Local & $4.80 \pm 0.37 \mathrm{ef}$ & $1.20 \pm 0.37 \mathrm{ef}$ & $0.25 \pm 0.08 \mathrm{bcd}$ & $2.20 \pm 0.37 \mathrm{~d}$ \\
Gorgan Local & $2.80 \pm 0.37 \mathrm{f}$ & $0.80 \pm 0.49 \mathrm{f}$ & $0.30 \pm 0.04 \mathrm{~d}$ & $1.40 \pm 0.40 \mathrm{~d}$ \\
\hline Means folow & $\mathrm{by}$ & & &
\end{tabular}

Means followed by the same letter are not significantly different at the $5 \%$ level according to Duncan's multiple range test.

different. Based on Duncan multiple range test, cultivars were grouped into 6, 6, 4 and 4 categories by leafminer stings, larval mines, and proportion of larval mines to leafminer stings and rate of injury traits, respectively. Finally, the cultivars were clustered based on all parameters and classified into four groups: susceptible ('Karim', 'Korazh', 'Zohal'), semi-susceptible ('Khasib', 'Jiroft 1', 'Evergreen', 'Vikima', 'Soltan'), semiresistant ('Super dominus', 'Maximus', 'Victor', 'Green magic', 'Royal', 'Serviceplus', 'Roodbar') and resistant ('Sanandaj', 'Gorgan') (Figure 1).

Local cultivars ('Gorgan', 'Sanandaj', 'Roodbar') had significantly fewer leafminer stings, larval mines and rate of injury than greenhouse lines ('Vikima', 'Korazh', 'Karim', 'Soltan', 'Green magic', 'Royal Evergreen', 'Jiroft 1', 'Khasib', 'Zohal') and field cultivars ('Service plus', 'Maximus', 'Victor', 'Super dominus') (Table 2).

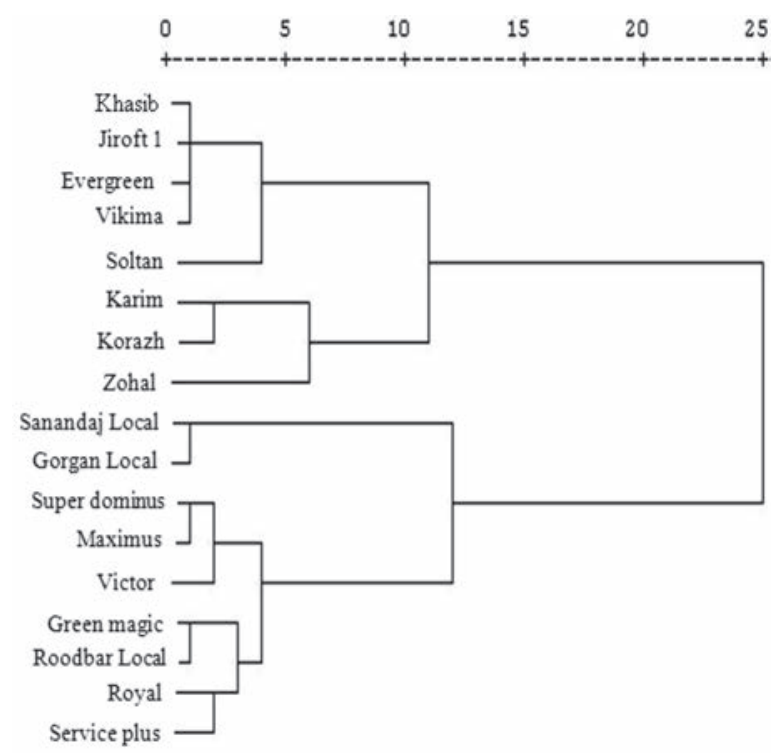

Figure 1. Ward's clustering dendrogram of resistance of 17 cucumber cultivars against Liriomyza sativae.

\section{Antibiosis trials}

Significant differences were found for all indices except sex ratio (Table 3). The oviposition period ranged from $3.12 \pm 0.05$ ('Karim') to $4.03 \pm 0.01$ ('Super dominus') (Table 4). The larval period varied from $4.36 \pm 0.1$ ('Karim') to $5.53 \pm 0.07$ ('Super dominus') and the maximum percentage of larval mortality was observed in 'Super dominus' ( $41 \pm 1.24 \%)$ and minimum percentage of larval mortality was observed in 'Karim' (10.80 \pm $0.29 \%$ ). The mean of pupal period ranged from $8.06 \pm$ 0.02 ('Karim') to $8.47 \pm 0 / 07$ ('Super dominus') and the maximum percentage of pupal mortality was observed in 'Super dominus' $(31.4 \pm 1.4 \%)$ and minimum percentage of pupal mortality was observed in 'Karim' (10.60 \pm $0.33 \%$ ) (Table 4 ). Finally, the cultivars were clustered using all parameters into three groups: sensitive ('Sultan',

Table 3. ANOVA for traits under study in leaves of six cucumber cultivars in antibiosis test.

\begin{tabular}{|c|c|c|c|c|c|c|c|}
\hline \multirow[b]{2}{*}{$\begin{array}{l}\text { Source of } \\
\text { variation }\end{array}$} & \multirow[b]{2}{*}{$\mathrm{dfz}$} & \multicolumn{6}{|c|}{ Mean squares } \\
\hline & & $\begin{array}{l}\text { Oviposition } \\
\text { period }\end{array}$ & $\begin{array}{l}\text { Larval } \\
\text { period }\end{array}$ & $\begin{array}{c}\text { Larval } \\
\text { mortality }\end{array}$ & $\begin{array}{l}\text { Pupal } \\
\text { period }\end{array}$ & $\begin{array}{c}\text { Pupal } \\
\text { mortality }\end{array}$ & Sex ratio \\
\hline & & 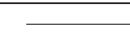 & 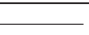 & $\%$ & $\mathrm{~d}$ & $\%$ & \\
\hline Cultivars & 5 & $1.069^{* *}$ & $1.725^{* *}$ & $1488.56^{* *}$ & $0.029^{* *}$ & $608.81^{\text {*** }}$ & $0.013 \mathrm{~ns}$ \\
\hline Error & 54 & 0.039 & 0.092 & 9.138 & 0.008 & 8.112 & 0.034 \\
\hline $\mathrm{CV}$ & - & 5.70 & 6.26 & 13.96 & 3.29 & 16.38 & 19.32 \\
\hline
\end{tabular}

dfz: degree of freedom; **Significant $\mathrm{F}$ tests at $\mathrm{P}=0.01$; ns: non significant.

Table 4. Mean $( \pm$ SE) for traits under study in leaves of six cucumber cultivars.

\begin{tabular}{|c|c|c|c|c|c|}
\hline Cultivar & $\begin{array}{c}\text { Oviposition } \\
\text { period }\end{array}$ & $\begin{array}{l}\text { Larval } \\
\text { period }\end{array}$ & $\begin{array}{c}\text { Larval } \\
\text { mortality }\end{array}$ & $\begin{array}{l}\text { Pupal } \\
\text { period }\end{array}$ & $\begin{array}{c}\text { Pupal } \\
\text { mortality }\end{array}$ \\
\hline & $\longrightarrow$ & - & $\%$ & d & $\%$ \\
\hline Gorgan Local & $3.47 \pm 0.08 \mathrm{bc}$ & $4.90 \pm 0.05 b c$ & $17.60 \pm 0.74 \mathrm{c}$ & $8.22 \pm 0.11 \mathrm{ab}$ & $15.20 \pm 0.41 \mathrm{c}$ \\
\hline Soltan & $3.21 \pm 0.04 \mathrm{~d}$ & $4.53 \pm 0.14 \mathrm{~cd}$ & $12.50 \pm 0.56 \mathrm{de}$ & $8.06 \pm 0.03 \mathrm{ab}$ & $12.00 \pm 0.53 \mathrm{~cd}$ \\
\hline Victor & $3.60 \pm 0.06 b$ & $5.04 \pm 0.02 b$ & $31.50 \pm 1.51 b$ & $8.27 \pm 0.04 \mathrm{ab}$ & $21.30 \pm 1.33 b$ \\
\hline Jiroft 1 & $3.35 \pm 0.08 \mathrm{~cd}$ & $4.70 \pm 0.12 \mathrm{bcd}$ & $15.70 \pm 0.81 \mathrm{~cd}$ & $8.15 \pm 0.06 b$ & $13.80 \pm 0.53 \mathrm{~cd}$ \\
\hline Super dominus & $4.03 \pm 0.01 \mathrm{a}$ & $5.53 \pm 0.07 a$ & $41.50 \pm 1.24 \mathrm{a}$ & $8.47 \pm 0.07 \mathrm{a}$ & $31.40 \pm 1.49 \mathrm{a}$ \\
\hline Karim & $3.12 \pm 0.05 \mathrm{~d}$ & $4.36 \pm 0.10 \mathrm{~d}$ & $10.80 \pm 0.29 \mathrm{e}$ & $8.01 \pm 0.02 b$ & $10.60 \pm 0.33 d$ \\
\hline
\end{tabular}

Means followed by the same letter are not significantly different at the 5\% level according to Duncan's multiple range test. 
'Jiroft', 'karim'), slightly resistant (local 'Gorgan', 'Victor') and semi-resistant ('Super dominus’) (Figure 2).

\section{Trichomes in the cultivars}

The counts of trichomes in the cultivars are presented in Table 5. Local cultivars ('Gorgan', 'Sanandaj', 'Roodbar') and field cultivar ('Super dominus') have the highest number glandular hairs and greenhouse cultivars ('Karim', 'Korazh', 'Zohal') had no glandular hairs.

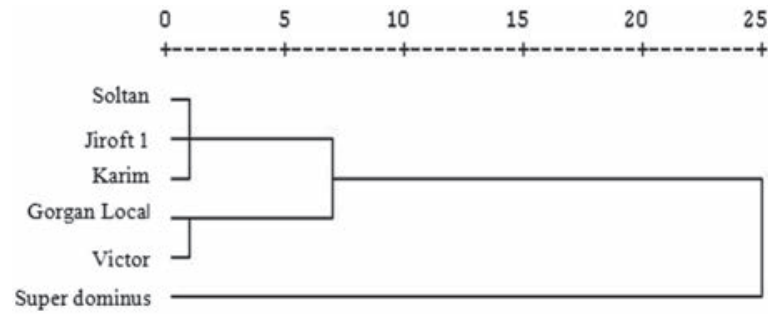

Figure 2. Ward's clustering dendrogram of the resistance of six cucumber cultivars against Liriomyza sativae in tests for antibiosis.

Table 5. Characteristics of trichomes in cucumber cultivars.

\begin{tabular}{lccc}
\hline Cultivars & $\begin{array}{c}\text { Short } \\
\text { trichomes }\end{array}$ & $\begin{array}{c}\text { Long } \\
\text { trichomes }\end{array}$ & $\begin{array}{c}\text { Glandular } \\
\text { trichomes }\end{array}$ \\
\hline Evergreen & Low & Low & Low \\
Karim & Low & Nil & Nil \\
Korazh & Low & Low & Nil \\
Vikima & Low & Low & Low \\
Zohal & Low & Low & Nil \\
Khasib & Low & Low & Medium \\
Jiroft1 & Medium & Medium & Medium \\
Royal & Medium & Medium & Medium \\
Green magic & Medium & Medium & Medium \\
Super dominus & Medium & High & High \\
Victor & Medium & Medium & Low \\
Maximums & Medium & Medium & Medium \\
Serviceplus & Medium & Medium & Medium \\
Soltan & Low & Low & Low \\
Roodbar Local & Medium & High & High \\
Sanandaj Local & High & High & High \\
Gorgan Local & High & High & High \\
\hline
\end{tabular}

\section{DISCUSSION}

All measured traits showed significant differences among the cultivars, suggesting that they differ in suitability to the leafminer, and that there is resistance to leafminer in cucumber germplasm. 'Karim' and 'Gorgan' had the most leafminer stings and least larval mines respectively. The correlation $(\mathrm{r}=0.85, \mathrm{p}<0.01)$ between both traits indicates a strong relationships, similar to studies of resistance to leafminers by Mou and Liu (2003) and Zahiri et al. (2003).

No cultivar was immune to injury. Therefore comparison of results among leafminer stings and larval mines to rate of injury showed that all of these traits are interdependent. Similar result was found in the study by Zahiri et al. (2003).

All traits measured (leafminer stings, larval mines, larval mines/leafminer stings, and rate of injury) to evaluate antixenosis were related. Thus, the number of stings per unit of leaf area is a feasible trait in selecting leafminer-resistant plants. Mou and Liu (2003) suggested that the number of stings per unit leaf is a more reliable trait for investigation of plant resistance to leafminers. As well, Zahiri et al. (2003) used four parameters (cited above), but leafminer stings were introduced for evaluation of cultivars of Apium graveolens (L.) to L. trifolii (Trumble et al., 2000). So, the index of leafminer stings has been confirmed by all researchers as the definitive criteria for evaluating resistance.

Local cultivars (Gorgan, Sanandaj, Roodbar) had significantly fewer leafminer stings, larval mines and rate of injury than greenhouses cultivars (Vikima, Korazh, Karim, Soltan, Green magic, Royal. Evergreen, Jiroft 1, Khasib, Zohal) and field cultivars (Service plus, Maximus F1, Victor, Super dominus) (Table 1). There are similar results for resistance of other crops to leafminers, for example, 46 lettuce genotypes were evaluated and results showed that wild species had significantly fewer leafminer stings than cultivated lettuce (Mou and Liu, 2003). An accession from another wild species, Apium nodiflorum (L.), demonstrated substantial insect toxicity and few mines were observed (Trumble et al., 1990). Among 345 accessions of the U.S. spinach collection for leafminer resistance, significant genotypic differences were found for leafminer stings per unit leaf area and mines per plant (Mou, 2008). These results suggest that greenhouses cultivars are generally more susceptible to the leafminer than the local cultivars and field cultivars. In the choice test, fewer stings per unit leaf area suggest host non-preference (antixenotic resistance). Resistance based on antixenosis would be desirable because even the photosynthetic losses caused by adult feeding and oviposition would be reduced. This could prompt leafminer movements to weeds or crops tolerant to insect damage, as suggested by Trumble et al. (1985).

Based on results of this research, in a stable temperature and without antagonistic insects, larval period and percentage of larval mortality are intensity affected by the host plant, and in this case, cucumber cultivars were related particularly to the larval period and the percentage of larval mortality. A study of resistance of chrysanthemum cultivars to L. trifolii, survival of $1^{\text {st }}$ and $2^{\text {st }}$ stage larvae was affected by plant resistance (Bottrell et al., 1998). As well, in a free-choice study of sources of resistance in celery genotypes under assay, resistant cultivars showed fewer leafminer stings and longer larval periods, indicating antixenosis and antibiosis resistance to L. trifolii (Trumble et al., 2000). In this research, significant differences were found in pupal period and pupal mortality. Similar results were found in evaluation of resistance of lettuce cultivars to L. sativae (Mou and Liu, 2004). However, in the study of resistance of bean varieties to leafminers, no significant differences were observed in the pupal period and the percentage of pupal 
mortality (Zahiri et al., 2005). Our results for antibiosis revealed genetic diversity among cucumber cultivars. For example, the percentage of larval mortality ranged from $10.8 \%$ in 'Karim' (greenhouse cultivar) to $41.50 \%$ in 'Super dominus' (field cultivars). This result does not indicate resistance in excess to $L$. sativae in the resistant cv. Super dominus, such that use of this cultivar will not lead to generating a resistant population of the insect. The cucumber cultivars clustered according to all measured characters were classified into three groups, similar to those of Zahiri et al. (2005) in the study of antibiosis of bean cultivars to L. sativae. Principal component analysis indicated that there is considerable diversity in cucumber cultivars for antixenosis and antibiosis components of resistance to L. sativae. Cultivars were assigned to different groups, from which both antixenosis and antibiosis to $L$. sativae can be used in resistance breeding programs to diversify the basis of resistance to this pest.

Glandular hairs are one of the resistant factors in cucumber to this leafminer. The genetics of glandular hairs is complicated and requires more study in the selected cultivars. More density of glandular hair was observed in local cultivars and likewise, the lowest density was observed in cultivars mainly planted in greenhouses. Furthermore, local cultivars were more resistant than greenhouse ones to the leafminer when screening for antibiosis. There is probably a direct inverse relationship between resistance and sensitivity of the cultivars and the presence and density of trichomas. Further studies should be conducted on their chemical basis.

Resistant cultivars remain the most economical means of insect control. Their use cuts down on the costs of chemicals, machinery, fuel and labor associated with pesticide spray. It also reduces the exposure of workers to hazardous chemicals. Insecticide residues in plants resistant to insects are reduced, and result in increased consumer acceptance of produce. It may also reduce pesticide contamination of soil and ground water, alleviating the pressure on the environment. Cucumber products free from leafminer stings and mines have potentially greater quality and value (Mou, 2008).

\section{CONCLUSION}

Our results indicate that greenhouse cucumber cultivars were generally more susceptible to L. sativae than the local and field cultivars. Resistance of these cucumber cultivars appear to be related to the presence of glandular hairs. Herein, a wide range of genetic variation in traits related to leafminer resistance was found in cucumber germplasm.

\section{ACKNOWLEDGEMENTS}

This work was conducted in the Plant Pest Research Institute, Varamin, Iran. Financial support was provided by Shahed University. The authors thank them all their support.

Evaluación de resistencia de cultivares de pepino a la mosca minadora (Liriomyza sativae Blanchard) (Diptera: Agromyzidae) en invernadero. La mosca minadora, Liriomyza sativae Blanchard, se ha distribuido por el mundo en recientes años y es una plaga importante de vegetales y plantas ornamentales. La resistencia potencial de la mosca minadora a insecticidas corrientes, el uso de cultivares resistentes, y parasitoides podrían ser estrategias efectivas en su manejo integrado de plagas (IPM). El pepino (Cucumis sativus L.) es un huésped preferido por este insecto. Diecisiete cultivares de pepino fueron evaluados para estudiar los mecanismos de resistencia a $L$. sativae, en pruebas de screening en invernadero usando índices tales como número de marcas hechas por la mosca, número de galerías larvales, proporción entre galerías larvales y marcas hechas por la mosca, y tasa de daño. Se observaron diferencias significativas $(\mathrm{p}<0,01)$ entre cultivares, así como correlaciones significativas entre los índices evaluados. Los cultivares de pepino se clasificaron por el método cluster basado en todos los caracteres medidos en cuatro grupos: susceptible, semi susceptible, semi resistente, y resistente. Los ensayos de resistencia a antibiosis de los cultivares se condujeron en cámara de crecimiento y se evaluaron con algunos índices biológicos de la actividad del insecto incluyendo período de ovipostura, duración de larvas y pupas, porcentaje de mortalidad de larvas y pupas, y proporción de sexos entre cultivares seleccionados. Se encontraron diferencias significativas para todos los índices, excepto peso de pupa y proporción de sexos. Los cultivares se analizaron por el método cluster para todos los caracteres medidos y se dividieron en tres grupos incluyendo sensibles, ligeramente resistentes, y semi resistentes. Ningún cultivar fue inmune al daño.

Palabras clave: Cultivar de pepino, screening, antibiosis, Cucumis sativus.

\section{LITERATURE CITED}

Bordat, D., M. Pitrat, C. Dogimont, and C. Pages. 1996. Resistance of Cucumis melo L. to Liriomyza trifolii (Burgess), Diptera: Agromyzidae. p. 90-91. In Calatayud, P.A., and B. Vercamber

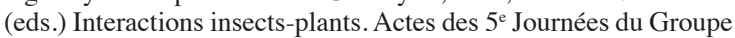
de Travail en Relations Insectes-plantes, Montpellier. 26-27 Octobre 1995. Collection Colloques CIRAD, Montpellier, France.

Bottrell, D.G., P. Barbosa, and F. Gould. 1998. Manipulating natural enemies by plant variety selection. Annual Review of Entomology 43:347-367.

Dijk, M.J., J. Jong, J.C.M. Knaap, E. Meijden, M.J. Van Dijik, J. Jong, et al. 1993. The interaction between Liriomyza trifolii and different chrysanthemum cultivars. Bulletin OILB-SROP 16:101108.

Erb, W.A., R.K. Lindquist, N.J. Flickinger, and M.L. Casey. 1993. Resistance of selected interspecific Lycopersicon hybrids to Liriomyza trifolii (Diptera: Agromyzidae). Journal of Economic Entomology 86:100-109.

Fathipour, Y., M. Haghani, A.A. Talebi, V. Baniameri, and A.A. Zamani. 2006. Natural parasitism of Liriomyza sativae (Diptera: 
Agromyzidae) on cucumber in field and greenhouse conditions IOBC/WPRS Bulletin 29:55-160.

Hondo, T., A. Koike, and T. Sugimoto. 2006. Comparison of thermal tolerance of seven native species of parasitoids (Hymenoptera: Eulophidae) as biological control agents against Liriomyza trifolii (Diptera: Agromyzidae) in Japan. Applied Entomology and Zoology 41:73-82.

Johnson, M.W.,E.R. Oatman, and J.A. Wyman. 1980. Natural control of Liriomyza sativae in pole tomatoes in southern California. Entomophaga 25:193-198.

Kaspi, R., and M.P. Parrella. 2005. Abamectin compatibility with the leafminer parasitoid Diglyphus isaea. Biological Control 35:172179.

Keil, C.B., and M.P. Parrella. 1990. Characterization of insecticide resistance in two colonies of Liriomyza trifolii (Diptera: Agromyzidae). Journal of Economic Entomology 83:18-26.

LeStrange, M., S. Koike, J. Valencia, and W. Chaney. 1999. Spinach production in California. University of California, Division of Agriculture and Natural Resources Publication 7212:3-4.

Mason, G.A., M.W. Johnson, and B.E. Tabashnik. 1987 Susceptibility of Liriomyza sativae and Liriomyza trifolii (Diptera: Agromyzidae) to permethrin and fenvalerate. Journal of Economic Entomology 80:1262-1266.

Minkenberg, O.P.J.M., and C.A.J. Helderman. 1990. Effect of temperature on the life history of Liriomyza bryoniae (Diptera: Agromyzidae) on tomato. Journal of Economic Entomology $83: 117-125$.

Mou, B. 2008. Leafminer resistance in spinach. HortScience 43:1716-1719.

Mou, B., and Y.B. Liu. 2003. Leafminer resistance in lettuce. HortScience 38:570-572.

Mou, B., and Y.B. Liu. 2004. Host plant resistance to leafminers in lettuce. Journal of the American Society for Horticultural Science 129:383-388
Parrella, M.P. 1983. Intraspecific competition among larvae of Liriomyza trifolii (Diptera: Agromyzidae): effects on colony production. Environmental Entomology 12:1412-1414.

Parrella, M.P., and J.T. Trumble. 1989. Decline of resistance in Liriomyza trifolii (Diptera: Agromyzidae) in the absence of insecticide selection pressure. Journal of Economic Entomology 82:365-368.

Reitz, S.R., and J.T. Trumble. 2002. Intraspecific and interspecific differences in two Liriomyza leafminer species in California Entomologia Experimentalis et Applicata 102:101-113.

Singh, K.B., and S. Weigand. 1996. Registration of three leafminerresistant chickpea germplasm lines: ILC 3900, ILC 5901, and ILC 7738. Crop Science 36:472-475.

SPSS. 2004. SPSS based 13.0 user's guide. SPSS Inc., Chicago, Illinois, USA.

Trumble, J.T., W. Dercks, C.F. Quiros, and R.C. Beier. 1990. Host plant resistance and linear furanocoumarin content of Apium accessions. Journal of Economic Entomology 83:519-525.

Trumble, J.T., M.M. Diawara, C.F. Quiros, N.J. Fokkema, M.A Beek, N.A.M. Steekelenburg, et al. 2000. Breeding resistance in Apiium graveolens to Liriomyza trifolii: antibiosis and linear furanocomarin content. XXV International Congress. Part 3: Culture techniques with special emphasis on environmental implications, Brussels, Belgium. Acta Horticulturae 513:29-37.

Trumble, J.T., I. Ting, and L. Bates. 1985. Analysis of physiological growth, and yield responses of celery to Liriomyza trifolii. Entomologia Experimentalis et Applicata 38:15-21

Zahiri, B., S. Moharramipour, A.A. Talebi, and Y. Fathipour. 2003. Antixenosis resistance of bean varieties to leafminer, Liriomyza sativae Blanchard (Diptera: Agromyzidae) in growth chamber. Journal of Entomological Society of Iran 23:59-75.

Zahiri, B., S. Moharramipour, A.A. Talebi, and Y. Fathipour. 2005 Antibiosis resistance of bean varieties to leafminer, Liriomyza sativae Blanchard (Diptera: Agromyzidae) in growth chamber. Iranian Journal of Agricultural Sciences 31:48-63. 